Gardner, R. A. W., D. G. Oscroft and A. K. Ntombela (2001): Final report on the 1992 Zululand site-species interaction trial series SGE32 to SGE34. ICFR Bulletin Series 17/2001. Pietermaritzburg, Institute for Commercial Forestry Research.

HARRAND, L., J. J. VARGAS HERNANDEZ, J. LOPEZ Upton and G. RAMIREZ VALVERDE (2009). Genetic parameters of growth traits and wood density in Eucalyptus grandis progenies planted in Argentina. Silvae Genetica 58: 11-19.

LEE, D. (2007): Relative performance of Corymbia hybrids and parental open-pollinated families in subtropical Queensland. In: Proceedings of "Eucalypts and Diversity: Balancing Productivity and Sustainability", IUFRO Working Party 2.08.03, Durban, South Africa, 22-26 October 2007.

Littell, R. C., G. A. Milliken, W. W. Stroup and R. D. Wolfinger (1996): SAS System for Mixed Models. SAS Institute Inc., Cary, NC, U.S.A.

Louw, A. K. (2006): Investigation of the application of best linear prediction for breeding and clonal production purposes in a Eucalyptus grandis population. MSc Thesis, University of KwaZulu-Natal, Pietermaritzburg.

Mahmood, K., N. E. Marcar, M. H. NaqVI, R. J. ARNold, D. F. Crawford, S. IQbal and K. M. Aken (2003): Genetic variation in Eucalyptus camaldulensis Dehnh. For growth and stem straightness in provenance-family trial on saltland in Pakistan. Forest Ecology and Management 176: 405-416.

NAMKOONG, G. (1979): Introduction to Quantitative Genetics in Forestry. U.S. Department of Agriculture. Technical Bulletin No.1588.

NDLOVU, Z. T. L. (2009): Breeding of advanced generation of Eucalyptus macarthurii - growth parameters and development of a non-destructive near infrared (NIR) calibration model for screening of pulping properties. MSc Thesis, University of KwaZulu-Natal, Pietermaritzburg.

SAS INSTITUTE (2002-2003): SAS/STAT Computer Software. Release 9.1.3. SAS Institute Inc. Cary, North Carolina, U.S.A.

Squillace, A. E. (1974): Average genetic correlations among offspring from open pollinated forest trees. Silvae Genetica 23: $149-156$.

SwAIN, T-L. and D. G. Oscroft (2003): First year height measurements of Eucalyptus henryi and E. longirostrata provenance trials in Zululand. ICFR Bulletin 06/2003. Institute for Commercial Forestry Research, Pietermaritzburg.

SwaIN, T-L. and D. G. OscrofT (2008): Performance of Eucalyptus longirostrata and Corymbia henryi on the Zululand Coastal Plain: Four year provenance/ progeny trial results. ICFR Technical Note 04/2008. Pietermaritzburg, Institute for Commercial Forestry Research.

Verryn, S. D., C. L. Snedden and R. C. Parfitt (2000): Program for the deterministic modelling of genetic gains of tree breeding and seed and clone production strategies. Southern African Forestry Journal 189: 3-9.

Verryn, S. D., C. L. SNedden and K. A. Eatwell (2007): A comparison of deterministically predicted genetic gains with those realised in a South African $E$. grandis breeding program. In: Proceedings of "Eucalypts and Diversity: Balancing Productivity and Sustainability", IUFRO Working Party 2.08.03, Durban, South Africa, 22-26 October 2007.

\title{
Changes in Genetic Diversity of Whitebark Pine (Pinus albicaulis Engelm.) Associated with Inbreeding and White Pine Blister Rust Infection
}

\author{
By A. D. Bower ${ }^{1), 2)}$ and S. N. AitkeN \\ Centre for Forest Conservation Genetics, Department of Forest Sciences, University of British Columbia, \\ 3041-2424 Main Mall, Vancouver, B.C. V6T 1Z4, Canada
}

(Received $9^{\text {th }}$ April 2010)

\begin{abstract}
We investigated the association of inbreeding and infection by the introduced disease white pine blister rust (caused by the fungus Cronartium ribicola J. C. Fisch) with genetic diversity of whitebark pine (Pinus albicaulis Engelm.) by genetically comparing cohorts of different ages in natural stands. Isozyme analysis of bud tissue was used to estimate expected and observed heterozygosity $\left(\mathrm{H}_{\mathrm{e}}\right.$ and $\left.\mathrm{H}_{\mathrm{o}}\right)$, and Wright's fixation index $\left(\mathrm{F}_{\mathrm{is}}\right)$ for three age cohorts (seedling, young, and mature),

\footnotetext{
1) Current Address: USDA Forest Service, Olympic National Forest, 1835 Black Lake Blvd. SW, Olympia, WA 98512. Phone 360-956-2405, Fax 360-956-2330. E-mail: abower@fs.fed.us

2) Communicating author: ANDREw D. BowER.
}

sampled from 14 sites in British Columbia, Oregon, Idaho, and Montana. Comparison of genetic diversity parameters among cohorts within a site was used to assess the extent and persistence of inbreeding with age, while comparisons of parameters among sites within a cohort were used to assess the impact of the disease on genetic diversity. Significant evidence of inbreeding $\left(F_{i s}>0\right)$ was found in all age cohorts. When sites were stratified by level of blister rust infection, differences in $\mathrm{F}_{\text {is }}$ and $\mathrm{H}$ among cohorts were only significant when level of infection was low. A significant negative association was found between level of blister rust infection and $\mathrm{H}_{0}$ in the mature cohort. This suggests that when differential selection due to blister rust is weak, more heterozygous individuals may be favored; however, more 
homozygous individuals may have higher fitness under higher blister rust levels

Key words: whitebark pine, Pinus albicaulis, white pine blister rust, genetic diversity, isozymes, inbreeding, cohort analysis, heterozygosity.

\section{Introduction}

Exotic diseases can have a devastating impact on populations that have not coevolved with pathogens and have little or no natural resistance, potentially leading to rapid declines in effective population size and loss of genetic variation. They pose unusual challenges to conservation because of their potential to drive rapid changes in host abundance and genetic composition (Altizer et al., 2003). Species in many genera of forest trees have been severely impacted by introduced diseases (e.g. Pinus, Chamaecyparis, Quercus, Castanea, Ulmus, Fagus, Juglans, Cornus) (BINGHAM et al., 1971; Ledig, 1991; DaUghtrey ans HibBen, 1994; Maloney et al., 2005; Loo, 2009), but data on the effects of these diseases on genetic structure and diversity is sparse. It is well known that disease can have a significant impact on both individual species and on the structural composition of forests (BURDON et al., 2006); however, empirical demonstrations of the effect of diseases on host demographics are difficult to conduct (ALEXANDER et al., 1996). In addition, studies of the effects of diseases on genetic diversity are difficult because baseline, pre-epidemic genetic data are impossible to collect after a disease has swept through (McDonALD et al., 1998).

Conifer populations often show increasing levels of heterozygosity with age, as embryos typically have a deficiency of heterozygotes, yet populations of mature trees usually have an excess (Plessas and STRAUSS, 1986; Politov et al., 1992; Ledig et al., 2000). The excess homozygosity in seeds is most likely due to inbreeding (LEDIG et al., 2000), including self-pollination and consanguineous matings, and selection against inbreds is the most likely reason for the reduction in $\mathrm{F}_{\text {is }}$ with age (KRUTOVsKII et al., 1995). For example, a study of Bosnian pine (Pinus leucodermis Ant.), which has reported selfing rates in the same range as whitebark pine (18-28\%), found that inbred individuals were not efficiently selected against during seed maturation and germination, but were eliminated by age five (MORGANTE et al., 1993). A heterozygote deficiency may be the result of genetic substructuring within stands producing a Wahlund effect, but in most cases, inbreeding appears to be the primary cause and this declines with age due to selection over time against more homozygous inbred individuals (Plessas and STRAUSS, 1986).

Whitebark pine (Pinus albicaulis Engelm.) experiences inbreeding from selfing, and to a lesser extent, consanguineous mating (KRAKOWSKI et al., 2003; BOWER and AITKEN, 2007). In addition, the inbreeding coefficient $\left(F_{i s}\right)$ of seedlings is higher than that of mature trees, indicating selection against inbred individuals over time (Bower and AITKEN, 2007). A previous study reported that $\mathrm{F}_{\text {is }}$ decreased and observed heterozygosity $\left(\mathrm{H}_{\mathrm{o}}\right)$ increased from west to east in whitebark pine in British Columbia (KRAKOwsKI et al., 2003). Stand-level infection by the introduced disease white pine blister rust (caused by the fungus Cronartium ribicola J. C. Fisch.) in British Columbia also increases from west to east (ZEGLEN, 2002), although infection varies widely among stands even within a mountain range (CAMPBELL and ANTOS, 2000). Trends in genetic diversity observed in British Columbia populations could be the result of either postglacial colonization patterns or selection by the disease against more homozygous, inbred individuals (KRAKOWSKI et al., 2003). However, in that study, any potential effects of inbreeding are confounded with the level of disease, due to the field sampling design.

The goals of this study were to examine the individual effects of inbreeding and blister rust infection on genetic diversity of whitebark pine. The effects of inbreeding were assessed by comparing $\mathrm{F}_{\text {is }}$ and $\mathrm{H}_{\mathrm{o}}$ among three age cohorts within populations, and the effects of blister rust were assessed by comparing these genetic diversity values for a given cohort among populations distributed across a wide geographic area.

\section{Materials and Methods}

\section{Sample Materials}

Thirty individuals from each of three age cohorts were sampled from 14 sites in British Columbia, Idaho, Montana, and Oregon in 2002 and 2003 (Table 1 and Figure 1). The seedling cohort was represented by three-yearold trees grown from seed collected from natural populations at these sites and grown in a common garden experiment in Vancouver, British Columbia. The young and mature cohorts were sampled in the field from the same natural stands where seeds were previously collected for the common garden experiment. The young cohort comprised trees estimated to be less than 30 years old, while the mature cohort included larger, older trees of reproductive age. To assess any potential genetic differences between putatively resistant (clean) and susceptible (infected) trees, the health status of each individual was recorded. Whitebark pine often grows in multistemmed clusters, and without genetic analysis, it is impossible to determine if these comprise one or more genotypes (TOMBACK and SchUSTER, 1994). Therefore, the stems in each cluster were conservatively regarded as comprising a single genotype and only a single stem was sampled from each cluster. If any stems in a sampled cluster were infected, that sample was considered to be from an infected individual. Buds were sampled from all individuals in both the field and the common garden experiment, and placed separately into separate plastic vials for transportation and subsequent storage at $-80^{\circ} \mathrm{C}$.

A disease infection survey was performed on each site to estimate the level of white pine blister rust infection. The survey protocol generally followed SMITH and HoFFMAN (2000). Strip transects were used to estimate stand infection levels by categorizing 50 trees on each site as 1) alive and clean: no evidence of blister rust; 2) infected and alive: alive with cankers, flagged or dead branches, or dead stems in multiple stemmed clumps with some living stems; 3) infected and dead: dead with clear evidence of blister rust cankers; or 4) dead unknown: dead 
but unable to determine cause of death. Four to six transects were assessed on most sites, except one site with very low whitebark pine density, where only one transect was completed which encompassed most of the trees on this site (Lunch Peak). Infection percentage was calculated as: \# of infected trees (both alive and dead)/ (total \# of trees assessed - \# dead from unknown causes). The mean infection percentage over all transects on a site was used to estimate the level of blister rust infection. For comparative purposes, sites were classified by infection level as low $(<50 \%$ infection, $n=5)$, moderate (50-75\% infection, $n=5$ ), or high ( $>75 \%$ infection, $n=4)$.

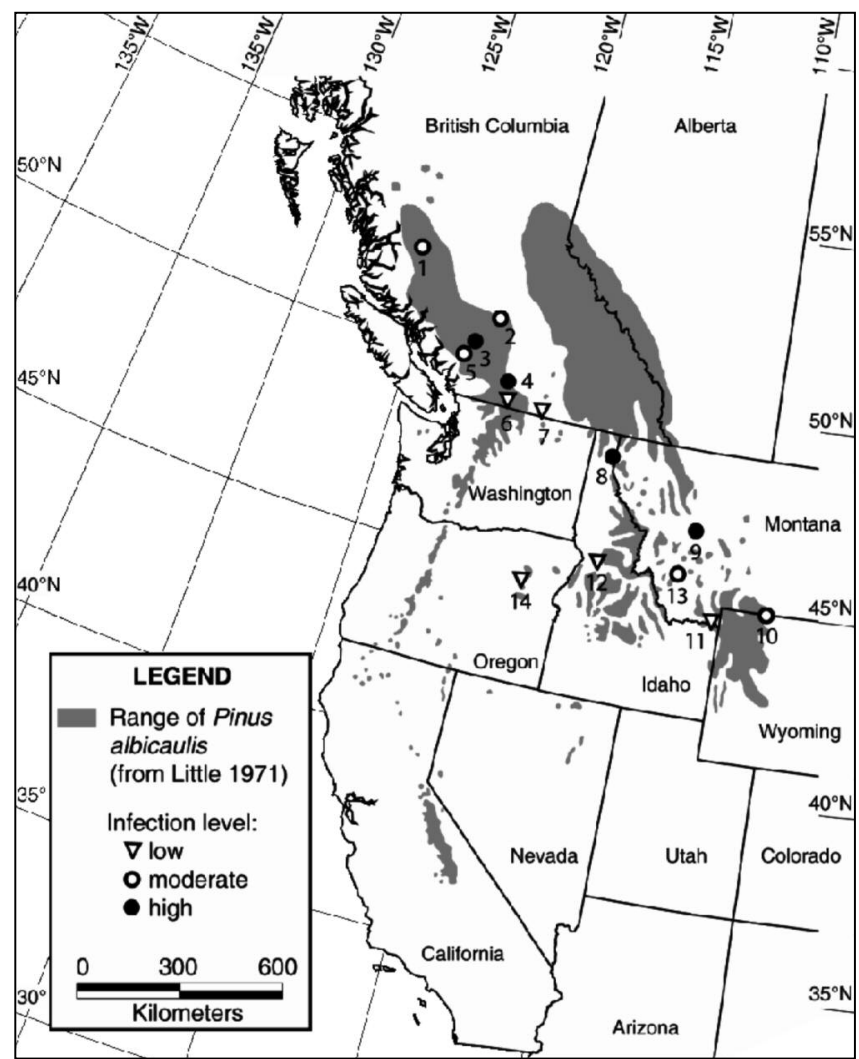

Figure 1. - Map of the range of whitebark pine and locations and level of blister rust infect of 14 sample locations. Infection level: low $=<50 \%$, moderate $=50-75 \%$, high $=>75 \%$.

\section{Isozyme Analysis}

Whole buds were ground in a buffer slightly modified from MitTon et al. (1977) and the supernatant absorbed onto 3 x $15 \mathrm{~mm}$ Whatman filter paper wicks. Samples were analyzed using starch gel electrophoresis on gels of $10.5 \%$ starch and $7.5 \%$ sucrose (w/v). Two buffer and electrode systems were used to analyze 10 loci as follows: 1) lithium borate/tris-citrate at a $\mathrm{pH}$ of 8.3 (SELANDER et al., 1971) was used for PGI (E.C. 5.3.1.9), SKDH 1, 2 (E.C. 1.1.1.25), PGM (E.C. 2.7.5.1), and TPI (E.C. 5.3.1.1); 2) histadine-EDTA (CHELIAK and PITEL, 1984) was used for $I D H$ (E.C. 1.1.1.42), $M D H ~ 1,2$ (E.C. 1.1.1.37), $G D H$ (E.C. 1.4.1.3) and $A L D$ (E.C. 4.1.2.13). Gels were electrophoresed with wicks in place at half voltage for 30 minutes, then wicks were removed and the lithium borate gels run at $300 \mathrm{~V}$ and the histadineEDTA gels run at $225 \mathrm{~V}$. Electrophoresis continued until a marker dye reached to within $1 \mathrm{~cm}$ of the edge of the gel. Gels were sliced and stained using recipes as detailed in CHELIAK and Pitel (1984), then fixed in a mixture of 1:5:5 glacial acetic acid:distilled water: methanol.

\section{Data Analysis}

The Fstat program (GoUDET, 1995) was used to calculate expected $\left(\mathrm{H}_{\mathrm{e}}\right)$ and observed $\left(\mathrm{H}_{\mathrm{o}}\right)$ heterozygosities and Wright's fixation index $\left(\mathrm{F}_{\text {is }}\right)$ (WRIGHT, 1951) for each cohort on each site. WEIR and CocKERHAM's (1984) $\Theta$ $\left(F_{\text {st }}\right)$ and $f\left(F_{\text {is }}\right)$ were estimated with Fstat for each cohort, and for sites grouped by infection level within each cohort. Fstat calculates F-statistics per locus and globally over all loci for a site or age cohort (GouDET, 1995).

SAS Version 8 (SAS INSTITUTE, 1999) was used for all statistical analysis. Means and standard errors were calculated for genetic parameters, and the differences among cohorts tested using PROC GLM for one-way analysis of variance (ANOVA) with a Duncan's multiple range test. The ANOVA was also conducted separately on groups of sites stratified by level of infection. Simple regression with PROC REG was used to determine if there was a significant association between level of blis-

Table 1. - Study site names, geographic locations, and white pine blister rust infection.

\begin{tabular}{llccccccc}
\hline No." $^{\text {a }}$ & Site Name & $\begin{array}{c}\text { State/ } \\
\text { Prov. }\end{array}$ & $\begin{array}{c}\text { Lat. } \\
(\mathbf{0} \mathbf{N})\end{array}$ & $\begin{array}{c}\text { Long. } \\
\text { ('W.) }\end{array}$ & $\begin{array}{c}\text { Elev. } \\
(\mathbf{m})\end{array}$ & $\begin{array}{c}\text { Infection } \\
\mathbf{\%}\end{array}$ & $\begin{array}{c}\text { \# mature } \\
\text { clean }\end{array}$ & $\begin{array}{c}\text { \# mature } \\
\text { infected }\end{array}$ \\
\hline 1 & Heckman Pass & BC & 52.5 & 125.8 & 1525 & 57.0 & 2 & 28 \\
2 & Jesamond & BC & 51.3 & 121.8 & 1850 & 55.4 & 12 & 18 \\
3 & D'Arcy & BC & 50.5 & 122.6 & 1800 & 81.0 & 6 & 24 \\
4 & Thynne Mt. & BC & 49.7 & 120.9 & 1785 & 82.5 & 11 & 19 \\
5 & Blackcomb & BC & 50.1 & 122.9 & 1900 & 71.0 & 20 & 10 \\
6 & Manning Park & BC & 49.1 & 120.7 & 2000 & 40.0 & 13 & 17 \\
7 & Mt. Baldy & BC & 49.2 & 119.3 & 2150 & 44.3 & 11 & 19 \\
8 & Lunch Peak & ID & 48.4 & 116.2 & 1850 & 81.6 & 5 & 25 \\
9 & Granite Butte & MT & 46.9 & 112.5 & 2340 & 82.2 & 3 & 27 \\
10 & Hellroaring & MT & 45.0 & 109.4 & 3000 & 70.0 & 8 & 22 \\
11 & Sawtel Peak & ID & 44.5 & 111.4 & 2400 & 47.5 & 16 & 14 \\
12 & Gospel Hill & ID & 45.6 & 115.9 & 2100 & 45.5 & 8 & 22 \\
13 & Quartz Hill & ID & 45.7 & 112.9 & 2650 & 62.7 & 12 & 18 \\
14 & Vinegar Hill & OR & 44.7 & 118.6 & 2340 & 30.1 & 26 & 4 \\
\hline
\end{tabular}

${ }^{\text {a }}$ Refers to number on figure 1 . 
ter rust infection and site latitude and longitude or genetic parameters.

Paired t-tests were performed on data from the mature cohort to determine if clean and infected trees paired by site differed in $\mathrm{H}_{\mathrm{o}}$ and $\mathrm{F}_{\mathrm{is}}$. Sites varied in the number of clean and infected trees in this cohort (Table 1). To eliminate potential confounding due to variation in sample size between clean and infected trees on each site, $\mathrm{F}_{\text {is }}$ was calculated as 1- $\left(\mathrm{H}_{\mathrm{o}}\right.$ for the group of clean or infected trees $/ \mathrm{H}_{\mathrm{e}}$ calculated for all trees on the site). The t-test was limited to sites that had a minimum of four individuals in each group.

\section{Results}

Significant inbreeding $\left(F_{\text {is }}>0\right.$ at $\left.\alpha=0.05\right)$ was detected in all cohorts when analyzed across all sites, even when sites were stratified by level of rust infection (Figure 2). Across all sites, differences in mean $\mathrm{F}_{\text {is }}$ values were marginally significant among cohorts $(p=0.056)$ but in the multiple range test, only means of the seedling and young cohorts were significantly different at $\alpha=0.05$. By locus, the difference among cohorts was only significant for SKD $1 \quad(p=0.014)$, with only the seedling and young cohort differing. Differences in $\mathrm{H}_{0}$ among sites were not significant when analyzed over all loci, but differed significantly for PGM and SKD 1 when loci were analyzed individually. In both cases, the seedling cohort differed from both the young and mature cohorts, When sites were stratified by the level of rust infection, the mean of the seedling cohort was significant different from the young and mature cohorts for both $\mathrm{F}_{\mathrm{is}}(\mathrm{p}=0.025)$ and $\mathrm{H}_{\mathrm{o}}(\mathrm{p}=0.039)$ when the rust level was low. However, no differences were detected among cohorts when the rust level was moderate or high (Figures 2 and 3 ).

When populations were analyzed by mountain range, average $\mathrm{H}_{e}$ and $\mathrm{H}_{0}$ were slightly higher in the Coast Range (populations 1-7 in Figure 1) $\left(\mathrm{H}_{\mathrm{e}}=0.222\right.$ and $\mathrm{H}_{\mathrm{o}}=0.188$ ) than in the Rocky Mountains (populations 8-14 in Figure 1) $\left(\mathrm{H}_{\mathrm{e}}=0.210\right.$ and $\left.\mathrm{H}_{\mathrm{o}}=0.177\right) . \mathrm{F}_{\text {is }}$ was

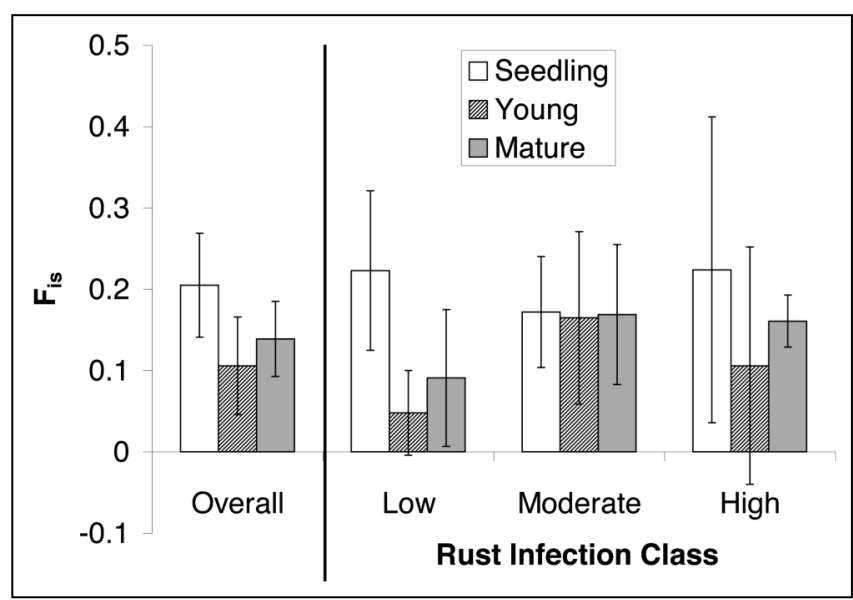

Figure 2. - Mean fixation index $\left(\mathrm{F}_{\text {is }}\right)$ by cohort for low, moderate, and high rust infection level sites (error bars are $95 \%$ confidence intervals determined by bootstrapping over loci 1000 times in Fstat).

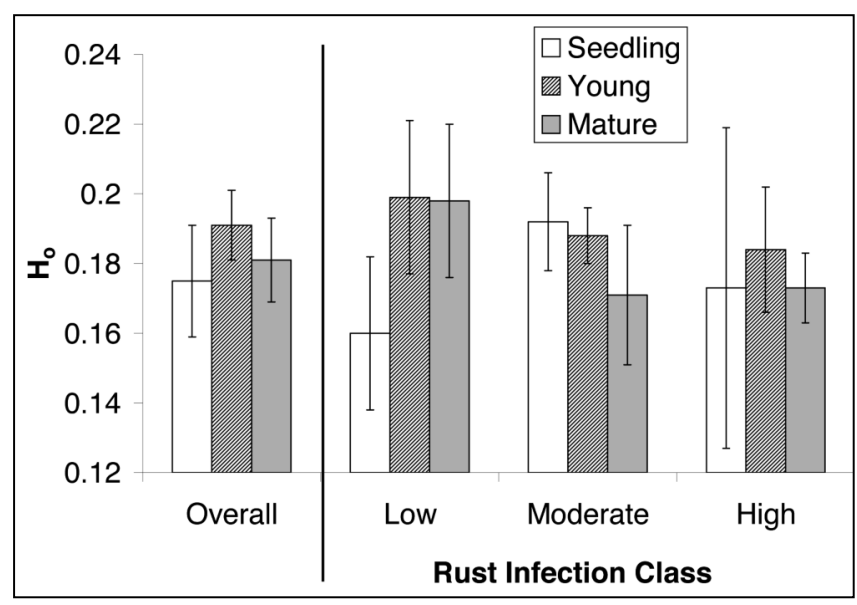

Figure 3. - Mean observed heterozygosity $\left(\mathrm{H}_{\mathrm{o}}\right)$ by cohort for low, moderate, and high rust infection level sites (error bars are $95 \%$ confidence intervals determined by bootstrapping over loci 1000 times in Fstat).

higher in the Rocky Mountains than in the Coast Range (0.156 vs. 0.144$)$; however, no differences were significant in T-tests of group means. No significant associations were found between stand level blister rust infection and latitude $\left(\mathrm{R}^{2}=0.081, \mathrm{p}=0.324\right)$ or longitude $\left(R^{2}=0.003, p=0.843\right)$. Regressions of the genetic parameters on latitude were only significant for $\mathrm{H}_{\mathrm{e}}$ in the young cohort $\left(R^{2}=0.334, p=0.031\right)$, and all regressions on longitude were not significant $(\mathrm{p}>0.05)$. Regressions of the genetic parameters for each of the cohorts with blister rust infection levels showed a significant association only for $\mathrm{H}_{\mathrm{o}}$ in the mature cohort $(\mathrm{p}=0.018)$. Plots of $\mathrm{F}_{\text {is }}$ and $\mathrm{H}_{\mathrm{o}}$ versus infection percentage indicated that the association between $\mathrm{F}_{\text {is }}$ and infection increased with cohort age while the association of $\mathrm{H}_{0}$ with infection decreases (Figures 4a-f). Figure $4 d$ shows one outlier site with high infection but low $\mathrm{H}_{0}$. This point represents Lunch Peak (site \#8 Figure 1, Table 1). This site had a very low density of whitebark pine, with large distances between trees. Only a single infection survey transect could be performed on this site because of the small population size. It is likely that the low density and wide spacing among whitebark pine trees at this site resulted in a higher rate of selfing. This is reflected in the high $\mathrm{F}_{\text {is }}$ (Figure $4 a$ - filled circle and table S1-supplimentary data) and low $\mathrm{H}_{0}$ values (Figure $4 d$ - filled circle and table $S 2$ - supplementary data) in the seedling cohort. Cook's distance can be used to measure the influence of a data point on a regression (WEISBERG, 1985), and the Cook's distance value for $H_{o}$ from this site was an order of magnitude higher than most of the other sites, indicating that this outlier had a large influence on the regression. When this data point was removed from the analysis, the regression of $\mathrm{H}_{0}$ on infection percentage for the seedling cohort was also significant $(\mathrm{p}=0.033)$, but with a positive slope (Figure $4 d)$.

Comparison of clean and infected trees within a site showed that for nine of the fourteen sites, $\mathrm{H}_{\mathrm{o}}$ was higher on average in the infected trees than in clean trees. However, paired T-tests for both $\mathrm{F}_{\text {is }}$ and $\mathrm{H}_{\mathrm{o}}$ showed that the differences between the group means were not sta- 


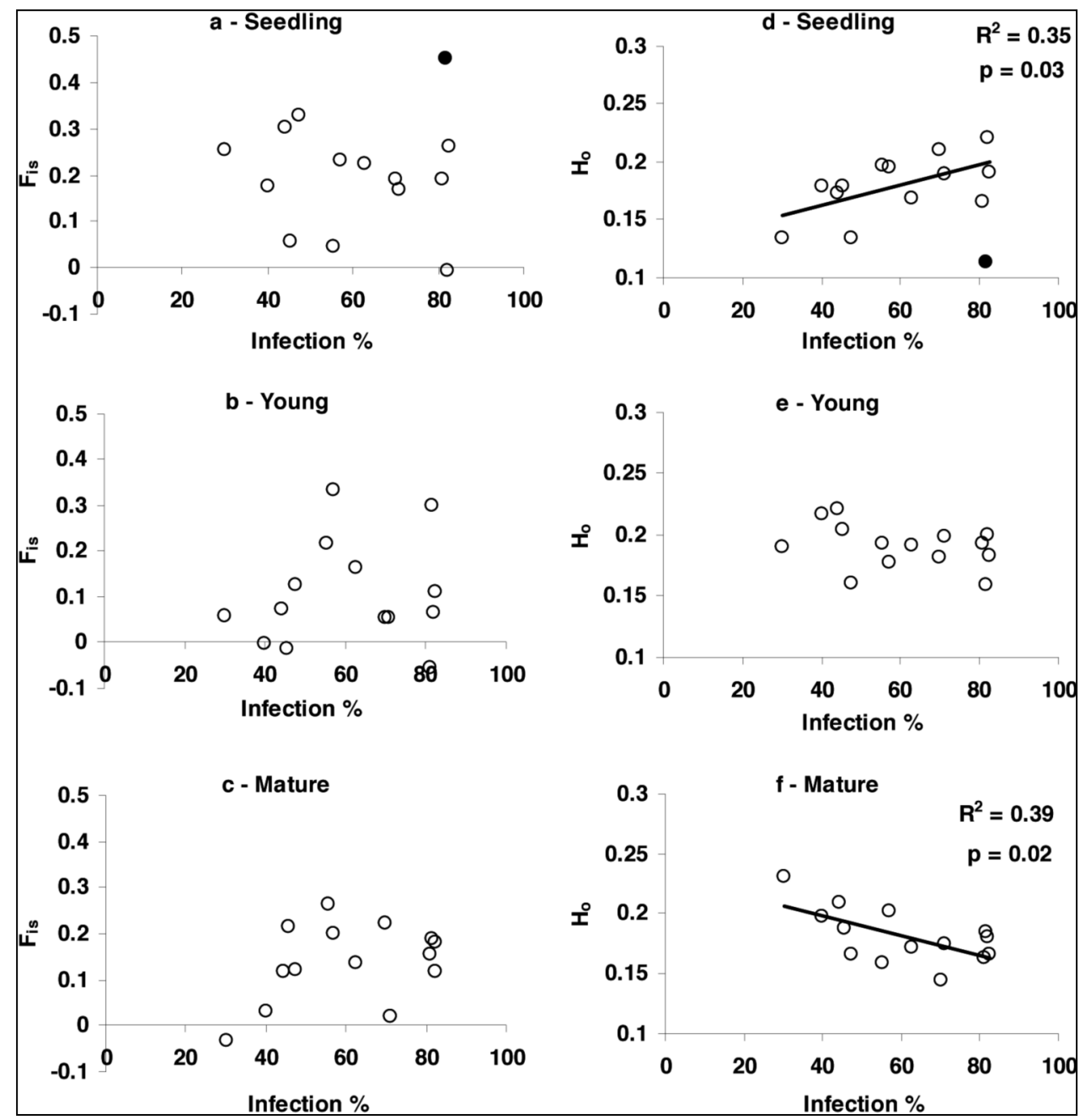

Figure 4. - Scatterplot of (a-c) fixation index $\left(\mathrm{F}_{\mathrm{is}}\right)$ and $(\mathrm{d}-\mathrm{f})$ observed heterozygosity $\left(\mathrm{H}_{\mathrm{o}}\right)$ of whitebark pine versus infection percent for 14 sites.

Table 2. - Fixation Indices $\left(\mathrm{F}_{\mathrm{is}}\right)$ at three life stages for several conifers.

\begin{tabular}{|c|c|c|c|c|}
\hline Species & $F_{\text {cmbryo }}$ & $F_{\text {secdling }}$ (age) & $F_{\text {mature }}$ (age) & Reference \\
\hline Pinus albicaulis & & $0.203(3)$ & 0.141 & This study \\
\hline$"$ & 0.093 & & $-0.034^{\mathrm{a}}$ & Bower and Aitken 2007 \\
\hline$P$. sibirica & $\sim 0.06$ & & -0.025 & Politov et al. 1992 \\
\hline P. koraiensis & $\sim 0.04$ & & -0.046 & Politov et al. 1992 \\
\hline P. cembra & 0.012 & & -0.174 & Krutovskii et al. 1995 \\
\hline P. pumila & 0.208 & & 0.009 & Politov et al. 2006 \\
\hline P. sylvestris & 0.143 & $0.266(10)$ & $-0.123(40)$ & Starova et al. 1990 \\
\hline$“$ & 0.12 & $0.006(3)$ & & Muona et al. 1987 \\
\hline$P$. radiata & 0.081 & $0.038(3-6)$ & $-0.119(17-20)$ & Plessas \& Strauss 1986 \\
\hline P. leucodermis & 0.126 & $-0.101(5)$ & -0.095 & Morgante et al. 1993 \\
\hline 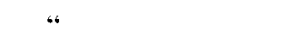 & 0.142 & $-0.121(5)$ & -0.079 & " \\
\hline P.ponderosa & 0.171 & -0.022 & & Farris \& Mitton 1984 \\
\hline P. monticola & 0.011 & & $-0.105(10-34)$ & El-Kassaby et al. 1987 \\
\hline P. banksiana & 0.010 & & -0.064 & Cheliak et al. 1985 \\
\hline P. washoensis & & $0.11(2)$ & -0.037 & Mitton et al. 1997 \\
\hline Pseudotsuga menziesii & 0.050 & & $-0.027(>25)$ & Shaw \& Allard 1982 \\
\hline Picea engelmanii & 0.081 & & $-0.034(<80)$ & Shea 1987 \\
\hline Abies lasiocarpa & 0.074 & & $-0.102(<80)$ & Shea 1987 \\
\hline A. bracteata & 0.388 & & 0.049 & Ledig et al. 2006 \\
\hline $\begin{array}{l}\text { Sequoiadendron } \\
\text { giganteum }\end{array}$ & 0.043 & & -0.021 & Fins \& Libby 1982 \\
\hline
\end{tabular}

${ }^{\text {a }}$ Determined from inferred maternal genotype. 
Table $S 1 .-\mathrm{F}_{\text {is }}$ values for 10 individual isozyme loci and over all loci from 14 sites.

A: Seedling cohort.

\begin{tabular}{lccccccccccc}
\hline Site & PGI 1 & MDH 1 & MDH 2 & SKD 1 & SKD 2 & IDH & GDH PGM 2 & ALD & TPI & Overall \\
\hline Heckman Pass & 0.15 & $*$ & 0.15 & 0.56 & 0.14 & -0.06 & $*$ & $*$ & $*$ & 0.23 & 0.23 \\
Jesamond & -0.06 & -0.04 & -0.13 & 0.21 & 0.32 & -0.06 & $*$ & 0 & $*$ & -0.07 & 0.05 \\
D'arcy & -0.02 & -0.02 & 0.49 & 0.16 & -0.01 & 0.00 & $*$ & 0 & $*$ & 0.21 & 0.19 \\
Thynne Mtn. & $-\mathbf{0 . 0 7}$ & 0.36 & 0.12 & 0.22 & 0.19 & -0.05 & $*$ & -0.02 & $*$ & -0.16 & 0.26 \\
Blackcomb & -0.02 & 1.0 & 0.40 & -0.04 & 0.06 & 0.10 & $*$ & $*$ & $*$ & -0.09 & 0.17 \\
Manning Park & -0.04 & 0.85 & 0.16 & 0.10 & 0.20 & -0.06 & $*$ & -0.06 & $*$ & -0.06 & 0.18 \\
Mt. Baldy & $-\mathbf{0 . 0 1}$ & 1.0 & 0.06 & 0.30 & 0.61 & 0.28 & $*$ & $*$ & $*$ & 0.37 & 0.30 \\
Lunch Peak & $*$ & 0.85 & 0.33 & 0.71 & 0.57 & $*$ & $*$ & -0.06 & $*$ & -0.14 & 0.45 \\
Granite Butte & -0.06 & -0.02 & 0.15 & -0.17 & -0.28 & -0.02 & $*$ & 0.66 & $*$ & 0.20 & -0.01 \\
Hellroaring & 0.01 & 0.66 & 0.25 & 0.07 & 0.32 & $*$ & $*$ & -0.04 & 1.0 & 0.13 & 0.19 \\
Sawlell Peak & 0.06 & -0.01 & 0.13 & 0.48 & $\mathbf{0 . 6 0}$ & $*$ & $*$ & 0 & $*$ & 0.00 & 0.33 \\
Gospel Hill & -0.18 & -0.02 & -0.17 & 0.31 & 0.16 & $*$ & $*$ & $*$ & $*$ & -0.02 & 0.06 \\
Quartz Hill & -0.08 & 0.37 & -0.12 & 0.40 & 0.39 & $*$ & $*$ & -0.02 & $*$ & 0.52 & 0.23 \\
Vinegar Hill & -0.06 & 0.66 & 0.18 & 0.65 & -0.02 & $*$ & $*$ & -0.09 & $*$ & 0.00 & 0.25 \\
\hline
\end{tabular}

* Monomorphic

B: Young cohort.

\begin{tabular}{lccccccccccc}
\hline Site & PGI 1 & MDH 1 & MDH 2 & SKD 1 & SKD 2 & IDH & GDH & PGM 2 & ALD & TPI & Overall \\
\hline Hcckman Pass & 0.29 & 0.0 & 0.66 & 0.22 & 0.65 & -0.14 & $*$ & $*$ & $*$ & 0.16 & 0.33 \\
Jesamond & 0 & 0.54 & 0.01 & 0.19 & 0.32 & -0.12 & $*$ & $*$ & $*$ & 0.38 & 0.22 \\
D'arcy & -0.06 & $*$ & -0.14 & -0.09 & -0.01 & -0.02 & 1.0 & -0.02 & $*$ & 0.02 & -0.05 \\
Thynne Mtn. & -0.06 & -0.02 & 0.15 & -0.13 & 0.38 & -0.04 & $*$ & 0 & $*$ & 0.17 & 0.11 \\
Blackcomb & 0.30 & -0.01 & 0.24 & -0.25 & 0 & -0.07 & $*$ & $*$ & $*$ & 0.15 & 0.06 \\
Manning Park & -0.01 & 0.37 & 0.04 & 0 & 0.01 & -0.06 & $*$ & $*$ & $*$ & -0.22 & 0 \\
Mt. Baldy & -0.03 & $*$ & -0.17 & 0.34 & 0.05 & -0.16 & $*$ & $*$ & $*$ & 0.24 & 0.07 \\
Lunch Peak & -0.04 & 0 & 0.39 & -0.10 & 0.38 & -0.06 & $*$ & 0.79 & $*$ & 0.47 & 0.30 \\
Granite Butte & 0.24 & 0 & 0.10 & 0.05 & 0.04 & 0. & $*$ & 0 & $*$ & -0.12 & 0.07 \\
Hellroaring & 0.25 & 0 & 0.09 & 0.08 & -0.09 & $*$ & $*$ & 0 & $*$ & -0.06 & 0.05 \\
Sawtell Peak & 0.25 & $*$ & 0.33 & -0.07 & 0.05 & $*$ & $*$ & $*$ & $*$ & 0.0 & 0.13 \\
Gospel Hill & -0.21 & $*$ & -0.19 & 0.14 & 0.01 & $*$ & 1.0 & $*$ & $*$ & -0.08 & -0.02 \\
Quartz Hill & 0.05 & 1.0 & -0.01 & 0.21 & -0.11 & $*$ & $*$ & 1.0 & 0 & 0.27 & 0.16 \\
Vinegar Hill & 0.66 & $*$ & 0.13 & 0.01 & -0.12 & 0 & $*$ & -0.04 & $*$ & 0.18 & 0.06 \\
\hline
\end{tabular}

* Monomorphic

C: Mature cohort

\begin{tabular}{lccccccccccc}
\hline Site & PGI 1 & MDH 1 & MDH 2 & SKD 1 & SKD 2 & IDH & GDH & PGM 2 & ALD & TPI & Overall \\
\hline Heckman Pass & 0.30 & $*$ & 0.07 & 0.18 & 0.58 & 0.26 & $*$ & $*$ & $*$ & -0.18 & 0.20 \\
Jesamond & 0.36 & $*$ & 0.02 & 0.50 & 0.67 & -0.10 & $*$ & $*$ & $*$ & 0.04 & 0.26 \\
D'arcy & $*$ & -0.04 & 0.11 & 0.10 & 0.39 & 0.0 & $*$ & -0.02 & $*$ & 0.02 & 0.15 \\
Thynne Mtn. & -0.02 & $*$ & 0.33 & -0.01 & 0.12 & -0.04 & $*$ & $*$ & $*$ & 0.12 & 0.12 \\
Blackcomb & -0.02 & 0 & 0.15 & -0.21 & 0.01 & -0.09 & $*$ & $*$ & $*$ & 0.13 & 0.02 \\
Manning Park & -0.06 & -0.02 & -0.23 & 0.16 & 0.16 & -0.01 & $*$ & 0 & $*$ & 0.11 & 0.03 \\
Mt. Baldy & -0.03 & 1.0 & 0.13 & 0.22 & 0.05 & -0.07 & $*$ & 0 & $*$ & 0.13 & 0.12 \\
Lunch Peak & 0.21 & 0.29 & -0.08 & 0.10 & 0.46 & -0.02 & 1.0 & $*$ & $*$ & 0.04 & 0.19 \\
Granite Butte & 0.03 & 0.0 & 0.34 & 0.27 & -0.09 & -0.02 & $*$ & 0 & $*$ & 0.53 & 0.18 \\
Hellroaring & 0.17 & -0.02 & 0.21 & 0.44 & 0.15 & $*$ & $*$ & 0 & $*$ & -0.06 & 0.22 \\
Sawtell Peak & 0.02 & 0 & 0.28 & 0.03 & 0.14 & $*$ & $*$ & 0 & $*$ & 0 & 0.12 \\
Gospel Hill & 0.76 & 0.66 & 0.07 & 0.09 & -0.13 & 1.0 & $*$ & 1.0 & $*$ & -0.13 & 0.22 \\
Quartz Hill & -0.08 & $\mathbf{0}$ & 0.23 & 0.02 & 0.14 & $*$ & $*$ & 1.0 & $*$ & 0.13 & 0.14 \\
Vinegar Hill & -0.21 & $*$ & 0.09 & -0.06 & 0.15 & 0 & $*$ & $*$ & $*$ & -0.29 & -0.03 \\
\hline
\end{tabular}

* Monomorphic

tistically significant $\left(\mathrm{p}=0.297\right.$ and 0.247 for $\mathrm{F}_{\text {is }}$ and $\mathrm{H}_{\mathrm{o}}$, respectively).

Genetic differentiation among populations varied among cohorts $\left(\mathrm{F}_{\mathrm{st}}=0.075,0.025\right.$, and 0.040 for the seedling, young, and mature cohorts, respectively), but all values are within the range previously reported for whitebark pine (YANDELL, 1992; JORGENSEN and HAMRICK, 1997; STUART-SMITH, 1998; RICHARDSON et al., 2002; KRAKOWSKI et al., 2003).

\section{Discussion}

We observed a significant decrease in $\mathrm{F}_{\text {is }}$ between the seedling and young cohort when the level of rust infection was low, but no differences among cohorts when the level of rust was moderate or high. In our study, inbreeding and blister rust affect the genetic diversity of whitebark pine in different ways. Inbreeding usually leads to lower genetic diversity within individuals and a heterozygote deficiency in seeds and seedlings, but this 
effect decreases over time as trees age and densitydependent selection occurs (Table 2). This pattern can be seen when the level of rust infection is low (Figure 2). However, when selection pressure due to blister rust is higher, heterozygosity levels are nearly the same across cohorts, and the heterozygote deficiency typical of seedlings was maintained in both young and mature trees in the more infected populations studied. Selection against heterozygotes by the rust may be a reason why $F_{\text {is }}$ values stay high in the young and mature cohorts on sites with higher infection levels, and why $\mathrm{H}_{\mathrm{o}}$ decreases with level of rust infection in the mature cohort. There are other reports of differentiation of enzyme loci associated with environmental variation which suggest that genotypes for specific enzymes may result in physiological differences that are acted on by natural selection

Table $S 2 .-\mathrm{H}_{\mathrm{o}}$ values for 10 individual isozyme loci and over all loci from 14 sites.

A: Seedling cohort.

\begin{tabular}{lccccccccccc}
\hline Site & PGI 1 & MDH 1 & MDH 2 & SKD 1 & SKD 2 & IDH & GDH & PGM 2 & ALD & TPI & Overall \\
\hline Heckman Pass & 0.35 & $* *$ & 0.30 & 0.21 & 0.43 & 0.20 & $*$ & $*$ & $*$ & 0.47 & 0.20 \\
Jesamond & 0.13 & 0.10 & 0.47 & 0.31 & 0.24 & 0.13 & $*$ & 0.05 & $*$ & 0.53 & 0.20 \\
D'arcy & 0.07 & 0.07 & 0.24 & 0.41 & 0.48 & 0.03 & $*$ & 0.05 & $*$ & 0.31 & 0.17 \\
Thynne Mtn. & 0.19 & 0.09 & 0.39 & 0.39 & 0.34 & 0.12 & 0.44 & 0.06 & $*$ & 0.30 & 0.19 \\
Blackcomb & 0.07 & 0.00 & 0.30 & 0.36 & 0.46 & 0.24 & $*$ & $*$ & $*$ & 0.47 & 0.19 \\
Manning Park & 0.10 & 0.04 & 0.41 & 0.35 & 0.41 & 0.14 & $*$ & 0.20 & $*$ & 0.15 & 0.18 \\
Mt. Baldy & 0.33 & 0 & 0.48 & 0.35 & 0.20 & 0.13 & 0 & 0 & 0 & 0.23 & 0.17 \\
Lunch Peak & $*$ & 0.03 & 0.33 & 0.13 & 0.22 & $*$ & $*$ & 0.13 & $*$ & 0.28 & 0.11 \\
Granite Butle & 0.18 & 0.07 & 0.43 & 0.54 & 0.60 & 0.07 & $*$ & 0.03 & $*$ & 0.29 & 0.22 \\
Hellroaring & 0.57 & 0.03 & 0.38 & 0.44 & 0.34 & $*$ & $*$ & 0.10 & 0 & 0.23 & 0.21 \\
Sawtell Peak & 0.27 & 0.07 & 0.45 & 0.27 & 0.22 & $*$ & $*$ & 0.03 & $*$ & 0.03 & 0.13 \\
Gospel Hill & 0.33 & 0.07 & 0.55 & 0.36 & 0.41 & $*$ & $*$ & $*$ & $*$ & 0.07 & 0.18 \\
Quartz Hill & 0.19 & 0.10 & 0.62 & 0.31 & 0.28 & $*$ & $*$ & 0.07 & $*$ & 0.11 & 0.17 \\
Vincgar Hill & 0.15 & 0.05 & 0.40 & 0.17 & 0.35 & $*$ & $*$ & 0.20 & $*$ & 0.03 & 0.13 \\
\hline
\end{tabular}

B: Young cohort.

\begin{tabular}{lccccccccccc}
\hline Site & PGI 1 & MDH 1 & MDH 2 & SKD 1 & SKD 2 & IDH & GDH & PGM 2 & ALD & TPI & Overall \\
\hline Hcckman Pass & 0.21 & 0.03 & 0.17 & 0.39 & 0.17 & 0.33 & $*$ & $*$ & $*$ & 0.46 & 0.18 \\
Jesamond & 0.03 & 0.10 & 0.52 & 0.41 & 0.33 & 0.23 & $*$ & $*$ & $*$ & 0.30 & 0.19 \\
D'arcy & 0.13 & $*$ & 0.43 & 0.47 & 0.33 & 0.07 & $*$ & 0.07 & $*$ & 0.43 & 0.19 \\
Thynne Mtn. & 0.13 & 0.07 & 0.35 & 0.57 & 0.30 & 0.10 & $*$ & 0.03 & $*$ & 0.29 & 0.18 \\
Blackcomb & 0.20 & 0.07 & 0.37 & 0.54 & 0.45 & 0.17 & $*$ & $*$ & $*$ & 0.20 & 0.20 \\
Manning Park & 0.27 & 0.10 & 0.37 & 0.41 & 0.47 & 0.13 & $*$ & $*$ & $*$ & 0.43 & 0.22 \\
Mt. Baldy & 0.33 & $*$ & 0.46 & 0.33 & 0.47 & 0.30 & $*$ & $*$ & $*$ & 0.31 & 0.22 \\
Lunch Peak & 0.11 & 0.03 & 0.24 & 0.50 & 0.30 & 0.13 & 0 & 0.03 & $*$ & 0.24 & 0.16 \\
Granitc Butte & 0.23 & 0.03 & 0.45 & 0.48 & 0.50 & 0.03 & $*$ & 0.03 & $*$ & 0.23 & 0.20 \\
Hellroaring & 0.23 & 0.03 & 0.39 & 0.46 & 0.53 & $*$ & $*$ & 0.03 & $*$ & 0.13 & 0.18 \\
Sawtell Peak & 0.20 & $*$ & 0.37 & 0.54 & 0.47 & $*$ & $*$ & $*$ & $*$ & 0.04 & 0.16 \\
Gospel Hill & 0.37 & $*$ & 0.60 & 0.43 & 0.47 & $*$ & 0 & $*$ & $*$ & 0.17 & 0.20 \\
Quartz Hill & 0.30 & 0 & 0.50 & 0.40 & 0.41 & $*$ & $*$ & 0 & 0.03 & 0.27 & 0.19 \\
Vinegar Hill & 0.03 & $*$ & 0.41 & 0.50 & 0.57 & 0.03 & $*$ & 0.10 & $*$ & 0.27 & 0.19 \\
\hline
\end{tabular}

* Monomorphic

C: Mature cohort

\begin{tabular}{lccccccccccc}
\hline Site & PGI 1 & MDH 1 & MDH 2 & SKD 1 & SKD 2 & IDH & GDH & PGM 2 & ALD & TPI & Overall \\
\hline Heckman Pass & 0.20 & $*$ & 0.40 & 0.35 & 0.21 & 0.33 & $*$ & $*$ & $*$ & 0.53 & 0.20 \\
Jesamond & 0.10 & $*$ & 0.43 & 0.23 & 0.14 & 0.21 & $*$ & $*$ & $*$ & 0.47 & 0.16 \\
D'arcy & $*$ & 0.10 & 0.37 & 0.41 & 0.31 & 0.03 & $*$ & 0.07 & $*$ & 0.33 & 0.16 \\
Thynne Mtn. & 0.07 & $*$ & 0.28 & 0.50 & 0.32 & 0.10 & $*$ & $*$ & $*$ & 0.39 & 0.17 \\
Blackcomb & 0.06 & 0.03 & 0.35 & 0.37 & 0.39 & 0.20 & $*$ & $*$ & $*$ & 0.35 & 0.18 \\
Manning Park & 0.13 & 0.10 & 0.57 & 0.38 & 0.33 & 0.07 & $*$ & 0.03 & $*$ & 0.37 & 0.20 \\
Mt. Baldy & 0.33 & 0 & 0.41 & 0.37 & 0.47 & 0.17 & $*$ & 0.03 & $*$ & 0.31 & 0.21 \\
Lunch Peak & 0.17 & 0.13 & 0.39 & 0.44 & 0.28 & 0.07 & 0 & $*$ & $*$ & 0.37 & 0.18 \\
Granite Butle & 0.33 & 0.03 & 0.30 & 0.37 & 0.53 & 0.07 & $*$ & 0.03 & $*$ & 0.13 & 0.18 \\
Hellroaring & 0.20 & 0.07 & 0.39 & 0.29 & 0.33 & $*$ & $*$ & 0.03 & $*$ & 0.13 & 0.14 \\
Sawtell Peak & 0.30 & 0.03 & 0.38 & 0.48 & 0.40 & $*$ & $*$ & 0.03 & $*$ & 0.03 & 0.17 \\
Gospel Hill & 0.10 & 0.03 & 0.46 & 0.43 & 0.57 & 0 & $*$ & 0 & $*$ & 0.29 & 0.19 \\
Quartz Hill & 0.17 & 0.03 & 0.32 & 0.50 & 0.40 & $*$ & $*$ & 0 & $*$ & 0.30 & 0.17 \\
Vinegar Hill & 0.37 & $*$ & 0.47 & 0.54 & 0.43 & 0.03 & $*$ & $*$ & $*$ & 0.47 & 0.23 \\
\hline
\end{tabular}

\footnotetext{
* Monomorphic
} 
(Mopper et al., 1991; MitTon, 1995). An alternate explanation may be that where selection or local mating system has produced highly heterozygous stands, rust infection levels do not reach moderate or high levels. This could be due to local environmental conditions in which more heterozygous individuals have higher fitness. However, while they were not statistically significant, our results showed that on individual sites, infected trees often have higher heterozygosity than clean trees, which argues against this hypothesis.

As the level of rust infection increases, overall $\mathrm{H}_{\mathrm{o}}$ of the mature trees within the stands we assessed decreased, yet the seed cohort produced from these stands had higher $\mathrm{H}_{\mathrm{o}}$ than stands with lower rust infection. One potential explanation for this is that if rust is killing stems or even just the cone-bearing branches of individuals within clusters, this could result in a reduction in matings among related individuals on sites with higher rust infection. This would lead to higher heterozygosity in the seed than in the mature individuals that are reproducing. A decrease in density leading to a loss of spatial genetic structure (e.g. due to harvesting) often has been reported to result in increases in inbreeding (MARQUARDT et al., 2007), and wind-pollinated species would be expected to show a positive relationship between population density and outcrossing rate (FARRIS and MitTON, 1984). However, empirical tests of this relationship are inconsistent (DYER and SoRK, 2001), and studies of the effect of different silvicultural treatments on genetic diversity showed an increase in heterozygosity in naturally regenerated seedlings of Pinus strobus after harvesting compared to old-growth populations (MARQUARDT et al., 2007). The authors suggested that logging decreased the spatial genetic structure, reducing spatially caused biparental inbreeding for the seedlings produced post-disturbance. The relationship we observed in $\mathrm{H}_{\mathrm{o}}$ in the seedling cohort may also reflect a decrease in selfing or biparental inbreeding in stands with higher rust infection, however, this cannot be tested with our data. This hypothesis is speculative, but warrants further investigation. A study to investigate genetic diversity in mature parent trees with their offspring that includes both a measure of local tree density and level of blister rust infection may be able to test this hypothesis.

Previous studies exploring the effects of disease epidemics on genetic diversity have yielded varying results in both forest trees and agricultural crops (MCDONALD et al., 1998; OuborG et al., 2000; KIM et al., 2003). In wild plant-pathogen populations, hosts should evolve towards increased resistance (GILBERT, 2002). However, it is not always possible to determine if changes in genetic diversity are correlated with increases in resistance (MCDONALD et al., 1998) and depending on the pathosystem, genetic control of resistance varies. For example, in a study of American beech (Fagus grandifolia Ehrh.), trees susceptible to beech bark disease had higher $\mathrm{H}_{0}$ values than resistant trees and showed an excess of heterozygotes, while resistant trees showed a deficiency of heterozygotes, suggesting recessive control of resistance (HoUSTON and HoUSTON, 2000). Conversely, a heterozygote excess detected in populations of Ameri- can chestnut (Castanea dentata) that have persisted through the chestnut blight epidemic through sprouting suggests that selection has favored more heterozygous individuals (STILWELL et al., 2003).

Introduced pathogens can result in high selection pressure when levels of natural resistance are low, and evolution towards increased resistance could result in decreased levels of diversity due to a genetic bottleneck or selective sweep. In a comparison of populations of western white pine (Pinus monticola), a closely related species in the Pinus subsection Strobus, KIM et al. (2003) found that a natural population under low rust pressure had higher polymorphism $(\mathrm{P})$ and heterozygosity $\left(\mathrm{H}_{\mathrm{e}}\right)$, and more private alleles than a population with high rust pressure. Assuming that levels of genetic diversity in the two populations were similar prior to invasion by blister rust, this suggests that selection by rust resulted in reduced diversity. Inferences regarding the level of resistance in the natural whitebark pine populations sampled in this study are not possible; however, if there is stronger differential selection on high rust sites, this may lead to higher levels of overall resistance in the remaining population, albeit at the risk of dramatic reductions in population size and genetic diversity, and even local extirpations if resistance genes are recessive.

Both dominant and recessive resistance genes have been identified in a variety of crop plants (ToYoDA et al., 2002; CHU et al., 2004). To date, only one dominant vertical resistance mechanism to blister rust (hypersensitivity) has been identified in the white pines (KINLOCH and DUPPER, 2002), while several horizontal mechanisms have been identified with dominant, recessive, and additive modes of inheritance hypothesized for a number of pine-rust pathosystems (see references in KINLOCH, 1982 and KINLOCH et al., 2008). Evidence of recessive gene segregation was found in early inoculation trials of western white pine (BINGHAM et al., 1960; BINGHAM, 1966) and recessive inheritance of genes conferring high resistance or immunity in Idaho western white pine were hypothesized by McDonALD and HofF (1970) and HoFf and MCDonALD (1971). Disease resistance genes are often dominant (BURDON, 2001) although about $10 \%$ of resistance genes in crops are recessive (BURDON and THOMPSON, 1995). In a large, truly panmictic population, recessive genes would rarely be expressed and thus would be of little selective value (BURDON, 2001), but forest trees typically have mixed mating systems with some selfing and bi-parental inbreeding (LEDIG, 1998). In wild populations, this mixed mating will facilitate the expression of recessive phenotypes produced by such alleles in some individuals. Although this will likely be associated with some inbreeding depression (WILLIAMS and SAVOLAINEN, 1996), the cost could be small compared with the selective advantage of disease resistance (BURDON, 2001).

The relationship between $\mathrm{H}_{\mathrm{o}}$ and level of blister rust infection found in our study suggests, but does not confirm, that more homozygous individuals have a higher fitness when challenged by blister rust possibly due to recessive genes for resistance being expressed under 
inbreeding. Our results suggest that, contrary to our expectations, more heterozygous individuals may be more likely than more homozygous whitebark pine genotypes to suffer mortality due to the introduced pathogen white pine blister rust. Whitebark pine may have some type of resistance to white pine blister rust that is recessively controlled. However, this must be confirmed by identification of specific resistance mechanisms and determination of their genetic control in common garden experiments with controlled exposure to spores of this introduced disease.

\section{Acknowledgements}

The authors thank the USDA Forest Service regions 1, and 6, the British Columbia Ministry of Forests, B.C. Parks E. C. Manning and Tweedsmuir Provincial Parks, and Вов BRETT of Snowline Ecological Consulting, Whistler, B.C. for providing seed for this study. DOROTHY Watson, Dane Szohner, Jodie Krakowski, and Milena SEMPRONI helped in the field and lab and CHRISTINE Chourmouzis created the map. Funding for this study came from the British Columbia Forestry Investment Account through the Forest Genetics Council of B.C. to the Centre for Forest Conservation Genetics. Thank you to Drs. Michael Whitlock, Alvin Yanchuk, Jeanette Whitton, ANDrew Eckert, JefF Mitton, and Sierra MCLANE for their helpful comments on an earlier draft of this manuscript.

\section{References}

Alexander, H. M., P. H. Thrall, J. Antonovics, A. M. JARosz and P. V. OUdEMANs (1996): Population dynamics and genetics of plant disease: a case study of anthersmut disease. Ecology 77: 990-996.

Altizer, S., D. Harvell and E. Friedle (2003): Rapid evolutionary dynamics and disease threats to biodiversity. Trends Ecol. Evol. 18: 589-596.

BINGHAM, R. T. (1966): Breeding blister rust resistant western white pine. III. Comparative performance of clonal and seedling lines from rust-free selections. Silvae Genet. 15: 160-164.

Bingham, R. T., A. E. Squillace and J. W. Wright (1960): Breeding blister rust resistant western white pine. II. First results of progeny tests including preliminary estimates of heritability and rate of improvement. Silvae Genet. 9: 33-41.

Bingham, R. T., R. J. Hoff and G. I. McDonald (1971): Disease resistance in forest trees. Annu. Rev. Phytopathol. 9: 433-452.

Bower, A. D. and S. N. Aitken (2007): Mating System and Inbreeding Depression in Whitebark Pine (Pinus albicaulis Engelm.). Tree Genet. Genomes 3: 379-388.

Burdon, J. J. and J. N. Thompson (1995): Changed patterns of resistance in a population of Linum marginale attacked by the rust pathogen Melapsora lini. J. Ecol. 83: 199206.

BuRDON, R. D. (2001): Genetic diversity and disease resistance: some considerations for research, breeding, and deployment. Can. J. For. Res. 31: 596-606.

Burdon, J. J., P. H. Thrall and L. ERICson (2006): The current and future dynamics of disease in plant communities. Ann. Rev. Phytopathol. 44: 19-39.
CAmpbell, E. M. and J. A. Antos (2000): Distribution and severity of white pine blister rust and mountain pine beetle on whitebark pine in British Columbia. Can. J. For. Res. 30: 1051-1059.

Cheliak, W. M. and J. A. Pitel (1984): Techniques for starch gel electrophoresis of enzymes from forest tree species. Can. For. Serv., Petawawa Natl. For. Inst. Rep. No. Pi-X-42.

Cheliak, W. M., B. P. Dancik, K. Morgan, F. C. Yeh and C. STRoBeck (1985): Temporal variation of the mating system in a natural population of jack pine. Genetics 109: $569-584$.

Chu, Z., Y. Ouyang, J. Zhang, H. Yang and S. WANG (2004): Genome-wide analysis of defense-responsive genes in bacterial blight resistance of rice mediated by the recessive $R$ gene $x a 13$. Mol. Genet. Genomics 271: $111-120$.

Daughtrey, M. L. and C. R. Hibben (1994): Dogwood anthracnose: a new disease threatens 2 native Cornus species. Annu. Rev. Phytopathol. 32: 61-73.

DYeR, R. J. and V. L. SoRK (2001): Pollen pool heterogeneity in shortleaf pine, Pinus echinata Mill. Mol. Ecol. 10: 859-866.

El-Kassaby, Y. A., M. D. Meagher, J. Parkinson and F. T. PoRTLOCK (1987): Allozyme inheritance, heterozygosity and outcrossing rate among Pinus monticola near Ladysmith, British Columbia. Heredity 58: 173-181.

FARRIS, M. A. and J. B. MitTon (1984): Population density, outcrossing rate, and heterozygote superiority in ponderosa pine. Evolution 38: 1151-1154.

FINS, L. and W. J. LIBBY (1982): Population variation in Sequoiadendron: seed and seedling studies, vegetative propagation, and isozyme variation. Silvae Genet. 31: 102-110.

GILBERT, G. S. (2002): Evolutionary ecology of plant diseases in natural ecosystems. Annu. Rev. Phytopathol. 40: $13-43$.

GouDET, J. (1995): Fstat version 1.2: a computer program to calculate Fstatistics. J. Hered. 86: 485-486.

HoFF, R. J. and G. I. McDonald (1971): Resistance to Cronartium ribicola in Pinus monticola: short shoot fungicidal reaction. Can. J. Bot. 49: 1235-1239.

Houston, D. B. and D. R. Houston (2000): Allozyme genetic diversity among Fagus grandifolia trees resistant or susceptible to beech bark disease in natural populations. Can. J. For. Res. 30: 778-789.

JoRGENSEN, S. M. and J. L. HAMRICK (1997): Biogeography and population genetics of whitebark pine, Pinus albicaulis. Can. J. For. Res. 27: 1574-1585.

KIM, M.-S., S. J. BRunsfeld, G. I. MCDonald and N. B. KLOPFENSTEIN (2003): Effect of white pine blister rust (Cronartium ribicola) and rust-resistance breeding on genetic variation in western white pine (Pinus monticola). Theor. Appl. Genet. 106: 1004-1010.

KINLOCH, B. B. (1982): Mechanisms and inheritance of rust resistance in conifers. In: Resistance to Pests and Diseases in Forest Trees. Proceedings of the $3^{\text {rd }}$ International Workshop on Genetics of Host-Parasite Interactions in Forestry, Sept. 1980. Wagenigen, The Netherlands.

KINLOCH, B. B. and G. E. DUPPER (2002): Genetic specificity in the white pine-blister rust pathosystem. Phytopathology 92: 278-280.

KINLOCH, B. B., D. A. DAVIS and D. BuRTon (2008): Resistance and virulence interactions between two white pine species and blister rust in a 30-year field trial. Tree Genet. Genomes 4: 65-74. 
KRAKowski, J., S. N. AitKen and Y. A. EL-Kassaby (2003): Inbreeding and conservation genetics in whitebark pine. Conserv. Genet. 4: 581-593.

Krutovskil, K.V., D.V. Politov and Y. P. Altukhov (1995): Isozyme study of population genetic structure, mating system and phylogenetic relationships of the five stone pine species (subsection cembrae, section strobi, subgenus strobus). In: P. BARADAT, W. T. ADAMs and G. MUller-Starck, (eds). Population genetics and genetic conservation of forest trees. SPB Academic Publishing, Amsterdam, The Netherlands, p279.

LEDIG, F. T. (1991): Human impacts on genetic diversity in forest ecosystems. Oikos 63: 8-108.

Ledig, F. T. (1998): Genetic variation in Pinus. In: Richardson, D. M. (ed) Ecology and biogeography of Pinus. Cambridge University Press, Cambridge p527.

Ledig, F. T., P. D. Hodgskiss and D. R. Johnson (2006): Genetic diversity and seed production in Santa Lucia fir (Abies bracteata), a relict of the Miocene broadleaved evergreen forest. Conserv. Genet. 7: 383-398.

Ledig, F. T., B. Bermejo-Velazquez, P. D. Hodgskiss, D. R. Johnson, C. Flores-Lopez and V. JACOB-CERVANTES (2000): The mating system and genetic diversity in Martinez spruce, an extremely rare endemic of Mexico's Sierra Madre Oriental: an example of facultative selfing and survival in interglacial refugia. Can. J. For. Res. 30: 1156-1164.

LitTLE, E. L., JR. (1971): Atlas of United States trees, volume 1 , conifers and important hardwoods. USDA For. Serv. Misc. Publ. 1146.

Loo, J. A. (2009): Ecological impacts of non-indigenous invasive fungi as forest pathogens. Biol. Invasions 11: 81-96.

Maloney, P. E., S. C. Lynch, S. F. Kane, C. E. Jensen and D. M. Rizzo (2005): Establishment of an emerging generalist pathogen in redwood forest communities. J. Ecol. 93: 899-905.

Marquardt, P. E., C. S. Echt, B. K. Epperson and D. M. PUBANZ (2007): Genetic structure, diversity, and inbreeding of eastern white pine under different management conditions. Can. J. For. Res. 37: 2652-2662.

McDonald, G. I. and R. J. Hoff (1970): Resistance to Cronartium ribicola in Pinus monticola: early shedding of infected needles. USDA Forest Service Research Note INT-124. Intermountain Forest and Range Experiment Station, Ogden, Utah, pp 8.

McDonald, G. I. and D. DEKKER-Robinson (1998): Long term differential expression of blister rust resistance in western white pine. Proceeding of the First IUFRO Rusts of Forest Trees Working Party Conference. Finnish Forest Resources Institute Research Paper No 712.

McDonald, B. A., B. K. Bellamy, J. Zhan and D. N. ApPel (1998): The effect of an oak wilt epidemic on the genetic structure of a Texas live oak population. Can. J. Bot. 76: 1900-1907.

MitTon, J. B. (1995): Genetics and the physiological ecology of conifers. In: SMith, W. K., Hinckley, T. M. (eds.) Ecophysiology of Coniferous Forests. Academic Press, New York p1.

Mitton, J. B., Y. B. Linhart, S. W. Sturgeon and J. P. FARRAR (1977): Protein polymorphisms detected in mature needle tissue of ponderosa pine. Am. J. Bot. 42: 1154-1157.

Mitton, J. B., R. G. LAtTA and G. E. Rehfeldt (1997): The pattern of inbreeding in Washoe pine and survival of inbred progeny under optimal environmental conditions. Silvae Genet. 46: 21-219.
Mopper, S., J. B. Mitton, T. G. Whitham, N. S. CobB and K. M. Christensen (1991): Genetic differentiation and heterozygosity in pinyon pine assocated with resistance to herbivory and environmental stress. Evolution 45: 989-999.

Morgante, M., G. G. Vendramin, P. Rossi and A. M. OLIVIERI (1993): Selection against inbreds in early livecycle phases in Pinus leucodermis Ant. Heredity 70: 622-627.

Muona, O., R. YAZDANi and D. Rudin (1987): Genetic change between life stages in Pinus sylvestris: allozyme variation in seeds and planted seedlings. Silvae Genet. 36: $39-42$.

OuborG, N. J., A. BierE and C. L. Mudde (2000): Inbreeding effects on resistance and transmission-related traits in the Silene-Microbotryum pathosystem. Ecology 81: 520-531.

Plessas, M. E. and S. H. Strauss (1986): Allozyme differentiation among populations, stands, and cohorts in Monterey pine. Can. J. For. Res. 16: 1155-1164.

Politov, D.V., K. V. Krutovski and K.V. Altukhov (1992): Isozyme loci characteristics of gene banks of populations of cedar pines. Genetika 28: 76-95.

Politov, D. V., M. M. Belokon and Y. S. BeloKon (2006): Dynamics of allozyme heterozygosity in Siberian dwarf pine Pinus pumila (Pall.) Regel populations of the Russian far east: comparison of embryos and maternal plants. Russ. J. Genet. 42: 1127-1136.

Richardson, B. A., S. J. BRUnsfeld and N. B. KLOPFENSTEIN (2002): DNA from bird-dispersed seed and winddisseminated pollen provides insights into postglacial colonization and population genetic structure of whitebark pine (Pinus albicaulis). Mol. Ecol. 11: 215-227.

SAS InSTITUTE (1999): The SAS system for windows. SAS Institute, Inc., Cary, North Carolina.

SElander, R. K., M. H. Smith, S. Y. YANG, W. E. Johnson and J. R. GENTRY (1971): Biochemical polymorphism and systematics in the genus Peromyscus I. Variation in the old-field mouse (Peromyscus polionotus). Stud. Genet. VI. 7103: 49-90.

SHAW, D.V. and R. W. Allard (1982): Isozyme heterozygosity in adult and open-pollinated embryo samples of Douglas-fir. Silva Fenn. 16: 115-121.

SHEA, K. L. (1987): Effects of population structure and cone production on outcrossing rates in Engelmann spruce and subalpine fir. Evolution 41: 124-136.

Smith, J. P. and J. T. HofFman (2000): Status of white pine blister rust in the Intermountain West. West. N. Am. Naturalist 60: 165-179.

Starova, N.V., Y. A. Yanbaev, N. K. Yumadilov, E. N. AdleR, V. A. DukHAREV and Z. K. ShigApov (1990): Genetic variability in age groups of scotch pine. Genetika 26: 314-319.

Stilwell, K. L., H. M. Wilbur, C. R. Werth and D. R. TAYLOR (2003): Heterozygote advantage in the American Chestnut, Castanea dentata (Fagaceae). Am. J. Bot. 90: 207-213.

StuART-SMith, G. J. (1998): Conservation of whitebark pine in the Canadian Rockies: blister rust and population genetics. Masters Thesis, University of Alberta, Edmonton.

Tomback, D. F. and W. S. Schuster (1994): Genetic population structure and growth form distribution in birddispersed pines. In: W. C. SCHMIDT and F. K. HoltmeIER (eds). International Workshop on Subalpine Stone Pines and Their Environment: The Status of Our Knowledge; 1992 September 5-11; St. Moritz, Switzerland; Gen. 
Tech. Rep. INT-GTR-309. U.S. Department of Agriculture, Forest Service, Rocky Mountain Research Station, Ogden, UT. p 43.

Toyoda, K., N. C. Collins, A. TAKahashi and K. SHIRAsU (2002): Resistance and susceptibility of plants to fungal pathogens. Transgenic Res. 11: 567-582.

WeIR, B. S. and C. C. CockerhaM (1984): Estimating Fstatistics for the analysis of population structure. Evolution 38: 1358-1370.

WeIsBerG, S. (1985): Applied Linear Regression. John Wiley \& Sons, New York. 324 pp.
Williams, C. G. and O. SAVOLAINEN (1996): Inbreeding depression in conifers: Implications for breeding strategy. Forest Sci. 42: 102-117.

WRIGHT, S. (1951): Evolution and the genetics of populations. Vol. II. University of Chicago Press, Chicago, IL.

YANDELL, U. G. (1992): An allozyme analysis of whitebark pine (Pinus albicaulis Engl.). Masters Thesis University of Nevada, Reno.

ZEGLEN, S. (2002): Whitebark pine and white pine blister rust in British Columbia, Canada. Can. J. For. Res. 32: 1265-1274.

\title{
Genetic diversity of Anadenanthera colubrina Vell. (Brenan) var cebil, a tree species from the South American subtropical forest as revealed by cpSSR markers
}

\author{
By M. E. Barrandeguy ${ }^{\left.1), 3),{ }^{*}\right)}$, M. V. García ${ }^{1), 3), 4), *)}$, C. F. Argüelles ${ }^{1)}$ and G. D. L. Cervigni ${ }^{2), 3)}$
}

(Received 14 ${ }^{\text {th }}$ April 2010)

\begin{abstract}
Anadenanthera colubrina var cebil is a tree species native to the Upper Parana Atlantic Forest where human activities have severely impacted causing deep fragmentation. Microsatellites are not available in this species. Therefore, the first objective of this study was to generate chloroplast simple sequence repeats (cpSSR) by cross-species transfer. Understanding the evolutionary dynamics of subdivided populations is an important matter. In this way, a first approach to the characterization of the haplotypic diversity within and between populations as well as the genetic structure of native Argentinean populations were the main goals of this study.

Twenty four individuals from two populations of the Misiones province were studied and four cpSSR loci were tested. Two of them exhibited polymorphic patterns leading to the identification of $11 \mathrm{cpDNA}$ haplotypes with high mean genetic diversity $(G D=0.73)$. The minimum spanning network defined three clear groups which can be assigned to at least three subpopulations. AMOVA indicated that the total variance showed the highest percentage of variation $(48 \%)$ within subpopulations with a fixation index $\left(\mathrm{F}_{\mathrm{ST}}\right)$ statistically significant $\left(\mathrm{F}_{\mathrm{ST}}=0.520 ; \mathrm{p}<0.05\right)$. Brown's two loci component analy-

1) Departamento de Genética. Facultad de Ciencias Exactas, Químicas y Naturales. Universidad Nacional de Misiones.

2) Centro de Estudios Fotosintéticos y Bioquímicos.

3) Consejo Nacional de Investigaciones Científicas y Técnicas (CONICET).

$\left.{ }^{4}\right)$ Corresponding author: MARIA Victoria García. Genética de Poblaciones y Cuantitativa, Departamento de Genética, Facultad de Ciencias Exactas, Químicas y Naturales, Universidad Nacional de Misiones, Félix de Azara 1552, (3300) Posadas. Misiones, Argentina. E-Mail: vgarcia@fceqyn.unam.edu.ar.

*) These authors contributed equally to this work.
\end{abstract}

sis indicated that substructure population is present. Jost's differentiation global index $\left(\mathrm{D}_{\text {est }}\right)$ was 0.049 while $\mathrm{D}_{\text {est }}$ pairwise comparison reflected a certain level of genetic structure.

The high diversity level detected in the adult trees of A. colubrina var cebil from the populations under study could be due to recent human influence. In this way, the reduction in population size caused a reduction in the number of trees leading to surviving trees showing the historical diversity of the populations analyzed.

Key words: Upper Parana Atlantic Forest, Curupay, intraspecific genetic diversity, cpSSR cross-species transfer.

\section{Introduction}

The study of the genetic diversity distribution, population structure and evolutionary features of a species native range is of particular relevance when evaluating their long-term variability and fitness (GómEz et al., 2002).

Anadenanthera colubrina Vell. Brenan var cebil, (Fabaceae, Mimosoideae) known locally as curupay, is a tree species native to the South American subtropical forest. Curupay trees can be found in the Upper Parana Atlantic Forest, which extends from Brazil into the northern part of Argentina, where human activities have had a severe impact leading to deep fragmentation. These trees can reach up to $35 \mathrm{~m}$ in height, with flowers arranged in hermaphrodite inflorescences and long legume fruits with narrow and flattened seeds (JUSTINIANO and FrederiCKsen, 1998; Cialdella, 2000). Their floral traits show that pollination is performed by bees and seed dissemination occurs over short distances by anemochory - autochory after pod dehiscence (JUSTI- 